\title{
Radioguided Occult Lesion Localization in Patients With Locally Recurrent Papillary Thyroid Carcinoma: How We Do It?
}

\section{Lokal ve bölgesel olarak nüksetmiş papiller tiroid kanserinde nüks lezyonların radyoaktif madde yardımlı (ROLL) saptanması ve tedavisi}

\author{
Mehmet Ali Gülçelik ${ }^{1}$, Lütfi Doğan ${ }^{1}$, Ilgın Şahiner ${ }^{2}$, Niyazi Karaman ${ }^{1}$, Gökhan Giray Akgül ${ }^{1}$, \\ Yavuz Selim Kahraman ${ }^{1}$, Gülin Uçmak Vural ${ }^{2}$ \\ ${ }^{1}$ Ankara Onkoloji Eğitim ve Araştırma Hastanesi, Genel Cerrahi Kliniği, Türkiye \\ ${ }^{2}$ Ankara Onkoloji Eğitim ve Araştırma Hastanesi, Nükleer Tıp Kliniği, Türkiye
}

Dergiye Ulaşma Tarihi: 30.11.2016 Dergiye Kabul Tarihi: 13.12.2016 Doi: 10.5505/aot.2017.96967

\begin{abstract}
ÖZET
Amaç: Papiller tiroid kanseri (PTK) tiroid bezinin en sık karşılaşılan kanseridir. Primer tedavi sonrası lateral boyunda \%50'nin üzerinde, santral bölgede ise \%25'in üzerinde bölgesel rekürrens ile karşılaşılır. Bu yazıda, preoperatif ultrason haritalama (PUH) ve Radioguided Occult Lesion Localization (ROLL) yöntemini kombine kullandığımız PTK rekürrensi nedeniyle reopere olmuş hastalardaki deneyimimizi sunmak amaçlanmıştır.

Yöntem: Daha önce PTK ve lokal bölgesel metastaz nedeni ile total tiroidektomi (TT) ve santral/lateral boyun diseksiyonu uygulanmış 8 hasta lokal bölgesel rekürrens nedeni ile reopere edildiler. Nükslerin araştırılmasında yüksek çözünürlüklü ultrasonografi, ince iğne aspirasyon sitolojisi ve kan Tg düzeyleri kullanıld1. Nüksleri ispatlanmış ve sitopatolojik incelemede yüksek Tg seviyeleri saptanan olgular opere edildiler. Her hastanın yaşı, cinsiyeti, primer tümör boyutu, ilk ameliyatın şekli, adjuvan tedavileri, nükse kadar geçen süresi, ameliyatın yeri ve süresi, işaretli ve işaretsiz lezyonların sayısı ve haritada işaretli/ işaretsiz lezyonlardaki ve haritada bahsedilmeyen lezyonlardaki metastatik ve çıkarılan lezyonların sayısı kaydedildi.

Bulgular: Lokalizasyon çalışması sonrası çıkarılan 20 lezyondan 16'sının malign olduğu görüldü. Haritalama sırasında işaretli lezyonlar dışında 36 ek lezyon da şüpheli olarak tanımlanmıştı. Bu lezyonların 34’ü tanımlanan anatomik yerleşimlerinde ve bölgelerde bulunarak çıkarıldı. İki lezyon ise haritalamada tanımlanan alanlarda bulunamad1. Bu 34 lezyondan 27'sinin malign olduğu gösterildi. Postoperatif takiplerde, bir hastada 7 günde kendiliğinden gerileyen şilöz kaçak ve seroma gelişti.

Sonuç: Santral ve boyun bölgesine reoperasyon planlanan PTK li hastalarda ROLL ve preoperatif haritalama tekniğinin ameliyat güvenliği ve konforuna katkı sağlar.
\end{abstract}

Anahtar Kelimeler: Tiroid kanseri, ROLL, papiller tiroid kanseri

\begin{abstract}
Introduction: Papillary thyroid carcinoma (PTC) is the most-frequent type of thyroid cancer. Following primary treatment, regional metastasis in the cervical region can be seen in more than 50 percent of cases and in the central region in more than 25 percent of cases. Our aim is to present our experiences with patients operated on for the recurrence of papillary thyroid cancer with the combined use of pre-operative ultrasonographic mapping and radio-guided occult lesion localisation.

Methods: Eight patients who had already undergone total thyroidectomy and central/lateral neck dissection for papillary thyroid carcinoma were re-operated on due to locoregional metastasis. High-resolution ultrasonography, fine needle aspiration cytology and blood Tg levels were used to search for recurrences. The patients with proven recurrences and high $\mathrm{Tg}$ wash-out levels in cytopathologic aspirates were operated on. For each patient, age, gender, size of the primary tumor, type of previous surgery, adjuvant treatments, time to recurrence, site and duration of surgery, numbers of marked and non-marked lesions, and the metastatic and total numbers of marked/non-marked and non-mentioned lesions in the maps were recorded.

Results: Sixteen lesions of 20 lesions removed after localisation were found to be malignant. In addition to the marked lesions during mapping, 36 additional lesions had been defined as suspicious. Thirty-four of these lesions were found at exact anatomic sites and localisations described and removed. Two lesions could not be found at areas described during mapping. Of 34 lesions, 27 were found to be metastatic. During the postoperative follow-up, chylous leak with spontaneous regression in 7 days and seroma occurred in one patient. Conclusion: Radio-guided occult lesion localisation and pre-operative mapping contribute to the safety and comfort of patients in planned re-operations on lateral and central neck regions.
\end{abstract}

Keywords: Thyroid cancer, ROLL, papillary thyroid carcinoma 


\section{Introduction}

Papillary thyroid carcinoma (PTC) is the mostfrequent type of thyroid cancer. Although it has a good prognosis, there is a tendency toward regional metastasis to central and lateral neck compartments (1). Following primary treatment, regional metastasis in the cervical region can be seen in more than 50 percent of cases and in the central region in more than 25 percent of cases (2). The negative contribution of local and regional recurrences of differentiated thyroid carcinoma for the long-term prognosis has already been demonstrated $(3,4)$. The primary treatment for recurrences is surgery. Micrometastases and residual tumoral tissues must be removed surgically. It has also been demonstrated that the remission of thyroglobulin $(\mathrm{Tg})$ levels after surgery is very frequent $(5,6)$. The treatment continues with radioactive iodine (RAI) ablation. The goal of surgical treatment is complete (R0) resection without leaving residual tissue. If this is not possible, the tumor burden has to be decreased as far as possible to prepare a ground for adjuvant treatment (7). As micrometastasis to neck lymph nodes is very frequent, surgical treatment as "pick up" to sample lymph nodes is not applicable for the goal of this surgery (8).

Surgical procedures applied to the neck region must have acceptable complication rates due to the important anatomical structures in the neck. Recurrent laryngeal nerve and parathyroid glands are at risk in surgical procedures applied to the central region. The intense scatritial tissues in patients who have undergone previous surgical procedures in the neck region distorts the anatomy and makes reoperation very difficult. In addition, it is very difficult to find small metastatic lesions in an area like this. Therefore, several new techniques have been described to increase surgical success and to decrease morbidity.

In this paper, our experiences with patients operated on for the recurrence of PTC with the combined use of pre-operative ultrasonographic mapping (PUM) and radioguided occult lesion localisation (ROLL) are presented.

\section{Materials And Methods}

Eight (8) patients who had already undergone total thyroidectomy and central/lateral neck dissection for PTC were re-operated on due to locoregional metastasis. High-resolution ultrasonography (USG), fine needle aspiration cytology (FNAC) and blood Tg levels were used to search for recurrences.

The patients with proven recurrences and high Tg wash-out levels in cytopathologic aspirates were operated on. Pre-operative written informed consent for the use of PUM and ROLL were obtained from the patients. The specialists in surgery and nuclear medicine assembled the morning of the surgery, and USG was repeated.

Those lesions that could be difficult for the surgeons to find and reach due to localisation were injected with $0.2 \mathrm{ml}$ of Tc $99^{\mathrm{m}}$ macroaggregated albumin with $20 \mathrm{MBq}$ activity under ultrasonographic guidance. Specific attempts were made to localise suspicious lesions close to the dissection margins. The lesions that were not suitable for injection due to anatomic localisation were defined in location to the lymph nodes, localised, and described in the mapping of the neck.

\section{Surgical procedure}

All operations were carried out by the same surgical team. Standard incisions were not used. According to the measurements of the gamma finder, the incisions made for the previous surgery, if possible, were preferred, and if this was not possible, the incisions with the shortest distance to the lesions were preferred.

After passing through the neck fascia, the lesions were oriented with the locations in the neck maps. Next, the marked, hot lesions were reached with the help of the gamma finder. The unmarked lesions were reached on the basis of their locations and proximity to the marked lesions. All other lesions encountered during surgery and not described in the maps were also removed. The complete excision of the marked lesions was ensured with the measurement of background activity. The radioactivity counts of the lesions and background activities were recorded. Before 
the completion of the surgery, the surgical field was explored once again with the gamma finder in order to locate any other non-marked lesions that were not described in the maps.

For each patient, age, gender, size of the primary tumor, type of previous surgery, adjuvant treatments, time to recurrence, site and duration of surgery, numbers of marked and non-marked lesions, and the metastatic and total numbers of marked/non-marked and nonmentioned lesions in the maps were recorded. The final pathology reports were evaluated carefully, and the anatomic distribution of the lesions removed was defined. Any surgical complications were recorded. Tg levels, USG, and screening with $\mathrm{I}^{131}$ were used for follow-up with the patients.

\section{Results}

A total of 8 patients ( 6 female and 2 male) were evaluated prospectively. The median age of the patients was 40.6 years $(17-54)$. The median tumor size was $17.6(6-35) \mathrm{mm}$. In addition to total thyroidectomies as initial surgeries, 3 patients had been operated on for ipsilateral central and lateral neck dissection, 3 patients for ipsilateral neck dissection, 1 patient for ipsilateral, and 1 patient for bilateral central neck dissection. Four (4) of the 6 patients who underwent surgery on the lateral neck had already been operated on at least twice in this area. All patients were given radioactive iodine.

The recurrence was detected at a median time of 33 (5-93) months from the primary surgery. The dissection areas at reoperation was as follows: unilateral level 2, 3, 4 and unilateral central regions in 3 patients; unilateral 2, 3, 4 and bilateral central regions in 4 patients; and unilateral 2, 3, 4 neck regions in 1 patient. The mean sizes of the lesions and metastatic lesions removed were $1.1 \mathrm{~cm}$ and $1.3 \mathrm{~cm}$, respectively. The longest and shortest operation times were 135 and 75 minutes, respectively. The mean operation time was 100 minutes (Table 1).

The mean 2.5 suspicious lesions were marked with radioactive substance in each patient. At least 1 and at most 5 lesions were marked. The complete removal of the lesions for each patient was proved with the gamma finder. Sixteen (16) lesions of 20 lesions removed after localisation were found to be malignant, and 4 lesions were benign. In addition to the marked lesions during mapping, 36 additional lesions had been defined as suspicious. The number of such suspicious lesions ranged between 1 and 16 .

Thirty-four (34) of these lesions were found at exact anatomic sites and localisations described and removed. Two (2) lesions could not be found at areas described during mapping. Of 34 lesions, 27 were found to be metastatic. Apart from the lesions described and marked at mapping, 58 additional lesions were detected at the examination of the specimens. These lesions were either macroscopically detected or undetected lesions during surgery and included in the specimens. The two lesions that could not be localised at mapping were probably included in this group. During pathological evaluation ot these 58 lesions, 7 were found to be malignant (Table 2).

During the postoperative follow-up, chylous leak with spontaneous regression in 7 days and seroma occurred in one patient. No other patient experienced complications. There was no RLN injury or hypocalcemia in patients operated on in the central neck area. There was a significant decrease in $\mathrm{Tg}$ levels within the first month of surgery in all patients operated on (Table 3). Ultrasonography was repeated two weeks after surgery by the physician who had performed the pre-operative evaluation, and no other suspicious lesions were described. 
Table 1: General features of the patients

\begin{tabular}{|c|c|c|c|c|c|c|c|c|}
\hline Patient & Age & Gender & $\begin{array}{c}\text { Tumor } \\
\text { size } \\
(\mathrm{mm})\end{array}$ & $\begin{array}{c}\text { First } \\
\text { operation }\end{array}$ & $\begin{array}{c}\text { Adjuvant } \\
\text { treatment } \\
(\mathrm{RAI} / \mathrm{mCi})\end{array}$ & $\begin{array}{l}\text { Recurrence } \\
\text { time (month) }\end{array}$ & $\begin{array}{l}\text { Operation } \\
\text { time (min) }\end{array}$ & $\begin{array}{l}\text { Operation } \\
\text { site }\end{array}$ \\
\hline 1 & 44 & $\mathrm{~F}$ & 20 & $\begin{array}{c}\mathrm{TT}+\mathrm{ICD} \\
+\mathrm{IND}\end{array}$ & 150 & 36 & 90 & IND+central \\
\hline 2 & 17 & $\mathrm{~F}$ & 15 & TT+IND & 100 & 7 & 115 & $\begin{array}{l}\text { IND+bilat. } \\
\text { central }\end{array}$ \\
\hline 3 & 45 & M & 20 & TT+IND & 350 & 16 & 100 & $\begin{array}{l}\text { IND+bilat. } \\
\text { central }\end{array}$ \\
\hline 4 & 46 & $\mathrm{~F}$ & 15 & $\begin{array}{c}\mathrm{TT}+\mathrm{ICD} \\
+\mathrm{IND}\end{array}$ & 350 & 29 & 105 & IND+central \\
\hline 5 & 49 & $\mathrm{~F}$ & 15 & $\begin{array}{l}\mathrm{TT}+\mathrm{ICD} \\
+\mathrm{IND}\end{array}$ & 300 & 93 & 85 & IND+central \\
\hline 6 & 54 & $\mathrm{~F}$ & 15 & TT+IND & 1150 & 33 & 135 & $\begin{array}{l}\text { IND+ bilat. } \\
\text { central }\end{array}$ \\
\hline 7 & 47 & M & 35 & $\mathrm{TT}+\mathrm{ICD}$ & 350 & 50 & 95 & IND+central \\
\hline 8 & 23 & $\mathrm{~F}$ & 6 & $\mathrm{TT}+\mathrm{BCD}$ & 150 & 5 & 75 & IND \\
\hline
\end{tabular}

TT: total thyroidectomy, ICD: ipsilateral central dissection, IND: ipsilateral neck dissection, BCD: bilateral central dissection, RAI: radioactive iodine

Table 2: The numbers of lesions preoperatively marked and removed

\begin{tabular}{|c|c|c|c|c|c|c|c|c|}
\hline Patient & $\begin{array}{l}\text { Marked } \\
\text { lesions }\end{array}$ & $\begin{array}{l}\text { Non- } \\
\text { marked } \\
\text { lesions }\end{array}$ & $\begin{array}{l}\text { Removed } \\
\text { marked } \\
\text { lesions }\end{array}$ & $\begin{array}{c}\text { Removed } \\
\text { non- } \\
\text { marked } \\
\text { lesions }\end{array}$ & $\begin{array}{c}\text { Metastatic } \\
\text { marked } \\
\text { lesions }\end{array}$ & $\begin{array}{c}\text { Metastatic } \\
\text { non- } \\
\text { marked } \\
\text { lesions }\end{array}$ & $\begin{array}{c}\text { Removed } \\
\text { extra } \\
\text { lesions }\end{array}$ & $\begin{array}{c}\text { Metastatic } \\
\text { extra } \\
\text { lesions }\end{array}$ \\
\hline 1 & 1 & 3 & 1 & 3 & 1 & 2 & 10 & 0 \\
\hline 2 & 2 & 3 & 2 & 3 & 2 & 3 & 12 & 2 \\
\hline 3 & 4 & 16 & 4 & 16 & 4 & 16 & 13 & 3 \\
\hline 4 & 2 & 2 & 2 & 2 & 2 & 0 & 7 & 0 \\
\hline 5 & 3 & 5 & 3 & 5 & 2 & 4 & 12 & 1 \\
\hline 6 & 5 & 3 & 5 & 3 & 2 & 0 & 1 & 0 \\
\hline 7 & 2 & 1 & 2 & 1 & 2 & 1 & 3 & 1 \\
\hline 8 & 1 & 3 & 1 & 1 & 1 & 1 & 0 & 0 \\
\hline
\end{tabular}


Table 3: Preoperative and postoperative Tiroglobuline levels

\begin{tabular}{|c|c|c|}
\hline Patient & Preop. Tg levels & $\begin{array}{c}\text { Postop. Tg } \\
\text { levels }\end{array}$ \\
\hline 1 & 63 & $<0.2$ \\
\hline 2 & 57 & $<0.2$ \\
\hline 3 & 537 & $<0.2$ \\
\hline 4 & 67 & $<0.2$ \\
\hline 5 & 82 & $<0.2$ \\
\hline 6 & 51 & $<0.2$ \\
\hline 7 & 115 & $<0.2$ \\
\hline 8 & 75 & \\
\hline
\end{tabular}

\section{Discussion}

Although long-term survival of PTC is quite good, locoregional control of the disease can be very difficult in some patients. Standard treatment in patients with lymph node metastasis $(\mathrm{N} 1 \mathrm{a} / \mathrm{b})$ of PTC is dissection of the central area (level VI) and lateral neck regions (levels II, III, IV) in addition to total thyroidectomy. Even so, recurrences can be seen at central and lateral neck regions during follow-up. The recurrences are more frequent in low- volume centers on central and lateral neck dissections, implying that the mostfrequent reason for recurrences is inadequate surgery (1). Although the additional benefit of surgical treatment of locoregional recurrences for long-term survival of PTC has been discussed for a long time, today it has been accepted that re-operations are needed for locoregional control, for the remission of $\mathrm{Tg}$ levels, and to allow for adjuvant treatment (9).

The surgical treatment of recurrences seen at central and lateral neck regions is quite challenging due to the difficult and complicated anatomy of the region and intense sicatritial tissues. At re-operations due to this recurrence, the following have been reported (10): $1-12 \%$ RLN injury, $1-3 \%$ permanent hypoparathyroidism, $\quad 0.8-1 \% \quad$ Horner's syndrome, $0.7-1 \%$ spinal accessory nerve injury, and $0.2-1 \%$ chylous leak due to ductus thoracicus injury. The neck metastasis of PTC can be seen in lymph nodes less than one centimeter. Residual metastatic deposits can be seen even after re-operations. Several technical modalities to assist surgical procedures and decrease morbidity and the risk of residual metastatic deposits have been popularized. Guide-wire localisation or dye injection under ultrasonographic guidance and radio-guided surgery (RGS) after systemic injection of radioactive substances are examples of these new techniques (11-14). Wire localisation is a difficult and rigorous technique for both patient and physician and can only localize single lesions. Blue dye has some systemic and local side effects such as skin necrosis. In addition, its rapid spread can stain other redundant tissues. The disadvantags of RGS are as follows: radioactive substance cannot be taken up by all metastatic deposits; if the operation starts before its removal from normal tissues, the counts can be obtained from all tissues; and radiation safety is lower for both physician and patient.

In the ROLL technique, the radioactive substance is injected under ultrasonographic guidance directly into the lesion. Therefore, it is easier to get return counts from the lesion. Additionally, there is no occurrence like low or no uptake of radioactive substance by iodine negative and dedifferentiated subtypes. Iodine $^{131}, \mathrm{I}^{123}$, Tc ${ }^{99 \mathrm{~m}}$ and F-18 FDG can be used for marking. As the dose of radioactivity used is low, the safety for the patient and physician is higher (15). The localisation by direct injection of radioactive substance into the lesion is advantageous, but not all lesions are suitable for this procedure due to their anatomic localisations. This problem can be eliminated with pre-operative neck mapping (6). Currently, high resolution USG is being used as a primary technique for the search of regional recurrences of PTC $(16,17)$. The use of USG and $\mathrm{Tg}$ levels for follow-up has decreased the need for whole-body scan with $\mathrm{I}^{131}$. Apart from the topographic localisation of the lesions, mapping with USG also reveals the relationship with the vital structures of the neck. ROLL also prevents unnecessary dissections in scatricial tissues. This technique also contributes to the selection of the mostsuitable incision. When the length of the 
surgery and the rate of complications are compared, a better orientation for the surgeon toward the lesion is obvious.

When we looked at the results in pathology reports, all marked lesions had been removed and only 2 of 36 lesions described in mapping could not be found. Of 56 suspicious lesions, 54 had been removed, and 43 of these was found to be malignant. Intentionally or not, 58 lesions that were not marked and not defined in mapping were also included in the specimen. The 2 lesions described in mapping that could not be removed were thought to be among these lesions; 7 of these lesions were metastatic. The metastatic lesions that could not be described during mapping were the most-important disadvantage of this technique. Therefore, surgeons should be careful, and the surgical field should be checked for suspicious lesions before closure of the wound. Some amount of radioactive subtance can pass through normal tissues, especially after injections to small lesions, but the complete removal of the lesion can be proven with the measurement differences of the radioactivity of the lesion and its bed. In a study of 8 patients with recurrent PTC by Ilgan et al, the combined technique was used and successful location and removal were reported to be quite high (18). In their series, the surgeons were asked about the contribution of this technique, and they reported it to be efficacious. When it is considered that all patients were operated on for a second or third time on the lateral neck and 7 patients on the central region, it can be said that the mean operation time of 100 minutes is quite acceptable and reasonable.

As a result, we believe that ROLL and pre-operative mapping contribute to the safety and comfort of patients in planned reoperations on lateral and central neck regions. Surgeons should also carefully examine the surgical field for the possibility of suspicious lesions that could not be defined during the pre-operative evaluation.

\section{Conflict of interest: None}

\section{References}

1. Mazzaferri EL, Kloos RT. Clinical review 128: current approaches to primary therapy for papillary and follicular thyroid cancer. J Clin Endocrinol Metab 2001; 86: 1447-63

2. Coburn M, Teates D, Wanebo HJ. Recurrent thyroid cancer: role of surgery versus radioactive iodine. Ann Surg 1994; 6: 587-95

3. Mazzaferri EL, Jhiang SM. Long-term impact of initial surgical and medical therapy on papillary and follicular thyroid cancer. Am J Med 1994; 97: 41828

4. Chow SM, Law SC, Mendenhall WM, et al. Follicular thyroid carcinoma: prognostic factors and the role of radioiodine. Cancer 2002; 95: 488-98

5. Bin Yousef HM, Alzahrani AS, Al Sobhi SS, Al SH, Chaudhari MA, Raef HM. Preoperative neck ultrasonographic mapping for recurrent/persistent papillary thyroid cancer. World J Surg 2004; 28 : $1110-1114$

6. Alzahrani AS, Raef H, Sultan A, et al. Impact of cervical lymph node dissection on serum TG and the course of disease in TG-positive, radioactive iodine whole body scan-negative recurrent/persistent papillary thyroid cancer. J Endocrinol Invest 2002; 25: $526-31$

7. Maxon HR III, Englaro EE, Thomas SR, et al. Radioiodine-131 therapy for well-differentiated thyroid cancer - a quantitative radiation dosimetric approach: outcome and validation in 85 patients. $\mathrm{J}$ Nucl Med 1992; 33: 1132-36

8. Grebe SK, Hay ID. Thyroid cancer nodal metastases. The biologic significance and therapeutic considerations. Surg Oncol Clin North Am 1996; 5: 43-63

9. Cooper DS, Doherty GM, Haugen BR, et al. Revised American Thyroid Association Management Guidelines for patients with thyroid nodules and differentiated thyroid cancer. Thyroid 2009; 19: 1167-214

10. Kim MK, Mandel SH, Baloch Z, et al. Morbidity following central compartment reoperation for recurrent or persistent thyroid cancer. Arch Otolaryngol Head Neck Surg 2004; 130: 1214-16

11. Salvatore M, Ruffini V, Reale F. Radio-guided surgery for lymph node recurrences of differentiated thyroid cancer. World J Surg 2003; 27: 770 -75

12. Gulec SA, Eckert M, Woltering EA. Gamma probeguided lymph node dissection (gamma picking) in differentiated thyroid carcinoma. Clin Nucl Med 2002; 27: 859-61

13. Agrawal A, Hall NC, Ringel MD, Povoski SP, Martin EW Jr. Combined use of perioperative TSH stimulated (18) F-FDG PET/CT imaging and gamma probe radioguided surgery to localize and verify resection of iodine scan-negative recurrent thyroid carcinoma. Laryngoscope 2008; 118: 2190 94

14. Rubello D, Salvatori M, Casara D, et al. 99mTcsestamibi radio-guided surgery of loco-regional 131Iodine-negative recurrent thyroid cancer. Eur J Surg Oncol 2007; 33: 902-06

15. Tukenmez M, Erbil Y, Barbaros U, et al. Radioguided nonpalpable metastatic lymph node localization in patients with recurrent thyroid cancer. J Surg Oncol 2007; 96: 534-38 
16. Priven I, Schwartz A, Yeh H. Ultrasonographic localization and marking of a small recurrent thyroid papillary carcinoma. Thyroid 2003; 13: 663-66

17. Kuna SK, Bracic I, Tesic V, Kuna K, Herceg GH, Dodig D. Ultrasonographic differentiation of benign from malignant neck lymphadenopathy in thyroid cancer. J Ultrasound Med 2006; 25: 1531-37
18. Ilgan S, Oztürk E, Yildiz R, et al. Combination of preoperative ultrasonographic mapping and radioguided occult lesion localization in patients with locally recurrent/persistent papillary thyroid carcinoma: a practical method for central compartment reoperations. Clin Nucl Med 2010; 35: 847-52 